Прегледни чланак

Tijana Žunić, Lawyer Trainee in Novi Sad

Tijana Đukić, Lawyer Trainee in Novi Sad

\title{
DEFENCE RIGHTS AND POLICE INVESTIGATION IN THE EU
}

\begin{abstract}
The abolition of the European borders has benefited a large number of people, allowing ordinary European citizens to move freely around and within the European Union. This, however, means that criminal organizations and terrorist groups have also gained their "paradise". Consequently, European attempts to combat crime had to overcome individual national actions by developing co-operation between the Member States. Police cooperation, as its integral part, was established on the bilateral and multilateral level. Nevertheless, the balance between strengthening of the police powers, on the one hand, and rights of individuals, on the other, has been disturbed. Has the EU overstepped the line and infringed basic human rights and fundamental freedoms, in particular considering right to privacy and defence of suspects? In order to find the answer the authors focused on the development of the police powers alongside the protection of the defendants' rights concerning three levels, i.e. national level of Member States, bilateral co-operation and multilateral co-operation in EU.
\end{abstract}

Key words: EU Criminal Law, the rights of the suspect, bilateral cooperation, Europol.

\section{INTRODUCTION}

The abolition of the European borders has been beneficial for different kinds of people. Consequently, ordinary European citizens have become able to move freely around and within European Union. However, criminal organizations and terrorist groups have gained their "paradise". In that sense, European attempts to combat crime had to overcome individual national actions by devel- 
oping co-operation between the Member States. Police co-operation, as its part, was established on the bilateral and multilateral level, with its legal basis settled in articles 87, 88, and 89 of the TFEU ${ }^{1}$. Nevertheless, the balance between strengthening of the police powers, on the one hand, and rights of individuals, on the other, has been disturbed. Does it seem that the EU has overstepped the line and forgotten the famous Kant's proverb: "Justice requires attention to the rights of the defendant as well as to the victim?"

This paper ${ }^{2}$ is focused on the development of the police powers alongside the protection of the defendants' rights concerning three levels, such as:

- National level of Member States

- Bilateral co-operation

- Multilateral co-operation in EU

\section{INCREASING POWERS OF THE POLICE ON NATIONAL LEVEL German example}

\subsection{Principle of discretionary prosecution-public prosecutor}

The trend towards increasing police powers, which started at the national level of individual states, has gathered momentum and is now a phenomenon that exists at the EU level.

Police can use their powers in two ways. One is to launch an investigation upon instructions from public prosecutor, while the other is to prevent the threat on their own initiative. ${ }^{3}$ The former has always been part of police investigation under the principle of mandatory prosecution, which dates back to the German Imperial Criminal Procedure Code of $1877,{ }^{4}$ still in effect today. Under the principle of mandatory prosecution initial suspicion is a necessary criterion for starting the investigation and prosecution. ${ }^{5}$ In that way criminal law is predictable and it ensures that police do not use their powers for repressive investigations. Giving the advantage to discretionary over mandatory principle significantly changed the role of the police in criminal law. In effect, the entire German criminal law was given a new meaning.

\footnotetext{
${ }^{1}$ Treaty on the Functioning of European Union.

${ }^{2}$ This paper was presented at the meeting held in Brussels May, 2010 before the highly regarded European officials and representatives.

${ }^{3}$ The German Code of Criminal Procedure (hereinafter StPO) Art 163.

${ }^{4}$ German Imperial Criminal Procedure Code, Strafprozessordnung, StPO, Bundesgesetzblatt, Federal Law Gazette; dating from 1877 as promulgated in 1987, April $7^{\text {th }}$ (BGBI .I, 1074, 1319) published in Schonfelder, no 90. Art.152 subs.2.

5 Peter-Alexis Albrecht, "The Forgotten Freedom”, 2003BWV Berlin, p. 88.
} 
By applying the principle of discretionary prosecution, more powers were given to both the public prosecutor and the police. Increasing informal prosecution infringes legal predictability in criminal law. For example, public prosecutor can dismiss the cases which have minor negative consequences and slight culpability if there is no public interest for prosecution. Article 153a of the German Code of Criminal Procedure has extended the powers to drop the case, subject to conditions that impose obligations on the accused. One example would be paying a sum of money to a non-profit institution. In that way prosecutor becomes the judge in preliminary investigation, that is, he becomes the judge in front of the judge. ${ }^{6}$ He decides if there is public interest to dismiss the case and what consequences this will have. This has led to a situation in which the same offence, committed by different individuals, may not be prosecuted in the same manner. ${ }^{7}$ Discretionary powers of public prosecutor can also be seen in the fact that he can choose in which local court to bring the case, or even to bring the case in front of the district court, although it should be submitted in a local court. Federal Court of Germany did not perceive this to be a violation of the principle of legitimate judge, even though that could mean that the accused would have recourse to fewer avenues of appeal. ${ }^{8}$ Imbalance between the powers of the prosecutors and the accused and violation of constitutional principles of independent judiciary is obvious. ${ }^{9}$

\subsection{Principle of discretionary prosecution-police}

"Strengthening of the police powers" 10 in Germany has been an ongoing process since the 1970s. At the time when the RAF terrorism emerged, police launched the "operative concept of combating criminals". In order to ensure public safety police powers were extended. Their task was no longer investigating single offences, but uncovering dangerous structural networks. ${ }^{11}$ For that reason, state police law provided the legal basis for using undercover agents, police monitoring and computer searches. The information obtained in the preliminary phase, long before initial suspicion ever existed, could be used in later proceedings. ${ }^{12}$ Furthermore, Criminal procedure law revoked prosecutors' and judges' control over the police who were performing these activities, explaining

6 Ibid. p.95.

${ }^{7}$ Ibid. p.92.

${ }^{8}$ Mireille Delmas- Marty and J.R. Spencer, European Criminal Procedures, 2002, Cambridge University Press, p. 307.

${ }^{9}$ Peter-Alexis Albrecht, op. cit., p. 95.

${ }^{10}$ Ibid.

${ }^{11}$ Ibid. p. 96.

${ }^{12}$ Ibid. 
that as too complicated. ${ }^{13}$ Certain procedural guarantees disappeared, for example right to a lawyer, while communication was limited. ${ }^{14}$ Federal Supreme Court even allowed admissibility of evidence collected in that way. Moreover, international telecommunications network could be monitored and used in this new scope of police duties.

Police powers were strengthened, while powers of the suspect were disregarded. Better organized and financially stronger police are always one step ahead. In contrast, defence lawyer cannot achieve similar progress due to the fact that reason for the suspicion of the crime is no longer controlled. In our opinion, the only thing defence lawyer can do in that case is to look for procedural irregularities, which is, of course, neither easy nor the best solution, but sometimes the only one.

\subsection{Police and defence lawyer}

In criminal proceedings, police powers are the strongest during the preparatory stage. While the public prosecutor and the police have the principal role, the judge can only supervise legality of coercive measures, ordered by the public prosecutor.

Although the suspect is guaranteed many significant rights in the German Code of Criminal Procedure, such as right to be heard, right to comment on the evidence, right to remain silent and right to assistance of a lawyer; these rights are in practice violated by the police and not always protected by the Court. ${ }^{15}$ Presence of a lawyer at this stage is obligatory only when the judge is interrogating the accused, ${ }^{16}$ but is optional when the examination is performed by public prosecutor ${ }^{17}$, and is not provided during interrogation conducted by the police. ${ }^{18}$ Moreover, when the police are reluctant to provide the arrested with his right to defence counsel he can use the right to remain silent. This is the most familiar right to the general public, unlike the one that states that when the presence of counsel is mandatory, the state will cover the costs ${ }^{19}$. Furthermore, there is obligation to inform the suspect of his right to remain silent, but there is no obligation to inform him of the right to have his costs covered. As a result,

${ }^{13}$ Ibid.

${ }^{14}$ Mireille Delmas- Marty and J.R. Spencer, op. cit., p. 310.

${ }^{15}$ GG Article 103, para 1, StPO163a and 136, StPO137.

${ }^{16} \mathrm{StPO} 168 \mathrm{c}(1)$.

${ }^{17} \mathrm{StPO} 168 \mathrm{a}(2)$ and $168 \mathrm{c}$.

${ }^{18}$ StPO163a (4).

19 Dr. Christian Fahl, Article, The Guarantee of Defense Counsel and the Exclusionary Rules on Evidence in Criminal Proceedings in Germany, June 2007,page no 1060, available at http://www.germanlawjournal.com/pdfs/Vol08No11/PDF_Vol_08_No_11_1053-

1067_Articles_Fahl.pdf 
the suspect may sometimes agree to be examined without presence of a lawyer, thereby making the position of the defence vulnerable. The police are aware that it is easier to extract a confession without the presence of a lawyer, so they try to obtain the first interview alone with the suspect. The police practice, not to help the accused unless they have to, is obvious. The case, in which an Italian citizen was taken into custody by the police, on suspicion of committing murder in Hamburg, confirms that. He was informed of the possibility to use the assistance of a lawyer, but as he could not understand German, and he could not find a lawyer that spoke Italian, eventually he confessed to the police. Later, it was proven that police knew a lawyer who spoke Italian, but they concealed that from the suspect, in order to obtain the confession. ${ }^{20}$

Another problem is that there is no rule in German law which stipulates that evidence obtained unlawfully cannot be used in the proceedings. ${ }^{21} \mathrm{Al}-$ though there are rules in German Criminal Procedure Code for excluding evidence, ${ }^{22}$ leading opinion in Germany is that too many restrictions make their use impossible. For example, taking blood samples is allowed without the suspect's consent, if that is necessary for the proceedings, on condition that such action does not violate his health and that blood is taken by a physician. ${ }^{23}$ On the contrary, Federal Court of Justice, in its early decision, ruled that evidence which is obtained by assistant doctor, who is not yet a legally qualified physician, can be used in court. ${ }^{24}$ The result is that blood samples are of the same quality, even though they have not been taken by a physician. There are other examples that illustrate discrepancies. For instance, the law stipulates that searches can be conducted only if they are ordered by judge or public prosecutor. ${ }^{25}$ However, in 1989 the Court ruled that evidence collected without judge's permission can be used in the proceedings, because object of proof was as good as the others. ${ }^{26}$

Article 136a sets out a list of methods that cannot be used. Those include "ill-treatment", "induced fatigue," "administration of drugs", "torment", "deception" and so forth, but sometimes it is hard to distinguish what is legal and what is illegal under this article ${ }^{27}$. For example, is it illegal to use confession, obtained after more than 20 hours of interrogation, or to keep heavy smoker away from cigarettes? These are only some examples, which highlight strong

${ }^{20}$ Ibid.

${ }^{21}$ Ibid.

${ }^{22}$ For example statement of witness who has not been informed of his right to silence, StPO Articles 52 to 55 .

${ }^{23}$ StPO Art 81(1).

${ }^{24}$ Dr. Christian Fahl, op.cit., p. 1062.

${ }^{25}$ StPO Art 105 (1).

${ }^{26}$ Dr. Christian Fahl, op.cit., p.1061.

${ }^{27}$ Ibid. p. 1063 
powers of the police and their great influence on the court. While they are interrogating the accused, the police are walking a thin law line. In order to obtain a confession, they do not choose the means. To avoid dismissing the case, the Court is willing to accept evidence collected in that way. Once again, that does not go in favour of defence lawyer.

On the one hand, defence lawyer cannot fight against army of police powers shown in using advanced methods of investigation, such as the above mentioned undercover investigations. On the other hand, we can see that police are given a lot of discretion when they are conducting interrogation without the presence of the lawyer.

\subsection{ECtHR ruling on the use of the police methods in investigations}

This imbalance of police powers has been reaffirmed in a number of ECtHR cases. The court provides the proof that the police do not respect the fundamental rights established in ECHR and Universal Declaration. Although ECtHR has formed the opinion that the use of undercover agents, telephone taps and other advanced methods of combating serious organized crimes is sometimes necessary, the right to a fair trial and the right to privacy are undoubtedly infringed. ${ }^{28}$ Furthermore, ECtHR's task is not to determine whether some evidence has been collected unlawfully under the national law, but to examine influence of this "unlawfulness" on infringement of some other rights protected by the Convention. ${ }^{29}$ The problem of controlling police when they are involved in secret operations and the status of evidence collected in that way is highlighted in the case Malinias v Lithuania. ${ }^{30}$ The existence of instigation to commit a criminal $\mathrm{act}^{31}$ shows how hard it is to control legality of police actions in secret investigations. Clear lack of equality in the adversarial process is immediately obvious in the use of the evidence obtained through secret operations against the accused that was not given the opportunity to comment on the evi-

${ }^{28}$ ECtHR case Perry v United Kingdom application no.63737/00, 2003, Mr. Perry, who was suspected of robbery, was covertly filmed by custody camera in police station. Court found that there was infringement of right of privacy by using tape for purpose of identification and showing it at the hearing.

${ }^{29}$ Lijana Stariene," The Limits of the Use of Undercover Agents and the Right to a Fair Trial under the Article 6(1) of ECHR", page no 272, available under www.mruni.eu/en/mokslo_darbai/jurisprudencija/archyvas/dwn.php? id. Ramanauskas v. Lithuania, § 52; Gafgen v. Germany, § 97; Khan v., § 34; P. G. and J. H. v. United Kingdom,

no. $44787 / 98, \S 76$, ECHR 2001-IX.

${ }^{30}$ ECtHR case no $10071 / 04$, Malinias v Lithuania.

31 Agent provocateur was intensively offering significant amount of money for the supply of large amount of drugs. In these cases it was proven that imitative was always coming from agent provocateur. 
dence $^{32}$. In the case of Edwards and Lewis v United Kingdom, ${ }^{33}$ in which applicants were arrested for committing crimes of drug traffic and money counterfeiting, prosecution based its charge on the grounds of secret information, which only the judge could examine. The same problems arise when using telephone taps. The right of the witness who wants to remain anonymous has to be respected, but in that way procedural right of the defendant to question the witness is infringed. ${ }^{34}$

While it is true that some defendants obtain justice in front of the ECtHR, that still does not imply the proper balance of powers, which should be ensured in pre-trial period and during the trial itself. The defendant's lawyer should be present during the interrogation of the accused by the police. A similar opinion was given by German government in the so-called consensual procedure. More involvement of defence counsel in preliminary phrase and his right to access the evidence will reduce its potential exclusion at the trial. ${ }^{35}$ When rights of defence counsel, as representative of the suspect, are properly secured there is less concern that the rights of the defendant would be violated. In that sense, they should be put on the same level as the rest of the trial participants. ${ }^{36}$

\section{BILATERAL POLICE COOPERATION BETWEEN THE MEMBER STATES}

Progress in the police investigation is not only present at the national level. Everything that has been prepared there has advanced at the European level with an even greater force. ${ }^{37}$

\subsection{Horizontal and vertical cooperation}

In 1985 following political agreement between the governments of the Benelux Economic Union, Schengen Agreement ${ }^{38}$ which abolished checks at their common borders, was concluded ${ }^{39}$. The next step was made with CISA which simplified police cooperation and mutual assistance, allowing further bilateral agreements between states which have common borders. After that a

${ }^{32}$ Lijana Stariene, op.cit. p.280.

33 ECtHR case, applications nos.39647/98 and 40461/98, 2004, Edwards and Lewis v. United Kingdom.

${ }^{34}$ Lijana Stariene, op.cit., p. 276.

${ }^{35}$ Peter-Alexis Albrecht, "The Forgotten Freedom", 2003BWV Berlin, p. 130.

${ }^{36}$ Ibid. p. 128 .

${ }^{37}$ Ibid. p. 100

${ }^{38}$ Available at OJ 2000, L 239/13.

${ }^{39}$ Andre Klip, European criminal law, 2009: $1^{\text {st }}$ edition, Antwerp-Oxford-Portland, p. 317. 
number of Conventions, Joint Actions, Recommendations, Resolutions, and Framework Decisions were adopted and amended. The most important document which regulates various forms of police cooperation is EU Mutual Assistance Convention. ${ }^{40}$

In order to comply with their obligations to combat crimes under the Treaties, Member States (MS) sometimes must seek the cooperation of other Member States. As in every field of European Law, the principle of sincere cooperation is applicable in criminal law. For the same reason, securing Union interest in criminal matters, the Commission is entitled to supervise the Member States; it can request certain information from them, but also has to supply available information to them. There are two possible forms of bilateral co-operation between the Member States in fighting crime. Horizontal co-operation is between the law enforcement authorities of two MS, while vertical co-operation is between the MS and the Commission.

\subsection{Horizontal cooperation}

Following from the general obligation of police authorities to assist each other, established in CISA as well as in EU Mutual assistance Convention, various methods of collecting evidence, exchanging information, building the skills and expertise, and building liaisons, were established or improved. Cross-border surveillance, covert investigation, joint investigation teams were regulated. In all these forms of cooperation, authorities use different models such as: the request model, mutual recognition model and availability model. The first and the last are the most important for police authorities. Under Article 4 of EU Mutual Assistance Convention, requested Member State which is executing the request must comply with the formalities and procedures expressly indicated by the requesting Member State. The aim is to facilitate the use of information which acts as evidence in the proceedings in the requesting MS. The problem arises when both countries, which have started proceedings and collected some evidence, need mutual assistance from each other, but each state has different rules for obtaining and using the evidence. These rules are based on conflicting balance of State's right to punish offenders and the fundamental right of individuals. ${ }^{41}$ Evidence which is not compatible with the rules of the issuing states will be proclaimed inadmissible in criminal proceedings. That situation hardly ever goes in favour of the accused. One possibility is that procedure will be terminated due to the lack of

${ }^{40}$ EU Mutual Assistance Convention from 29 May 2000, available at OJ,12/07/ 2000, C197.

41 Professor Dr h.c.mult. Bernd Schunemann, EURODEFENSOR, Balanced concept of criminal procedure inspired by the concept of the rule of law in Europe, page no 2, available at http://ec.europa.eu/justice_home/news/consulting_public/0004/civil_society/eurodefensor en.pdf 
evidence and it will be assumed that the acquitted will never obtain opportunity to prove that he would have been released even if he had stood trial. The other is that the procedure continues, but it will be really compromised.

On the other hand, sometimes it is hard for an individual to conclude which is the requesting and which is the requested state. That can violate human rights without recourse to judicial protection, not only under national law of individual states involved but also under ECHR. In the case Chinoy against the United Kingdom, ${ }^{42}$ ECtHR ruled that the applicant's allegation of illegal use of tape records in France by the USA undercover agents in proceedings in the UK was invalid. The reason was that the applicant appealed against the wrong state, in this case the UK. The unanswered question was: would his rights have been better secured if he had appealed against France, or maybe both countries, taking the risk of not exhausting all domestic remedies in both countries? However, we can see from this case that the English court accepted evidence which was obtained unlawfully under the French law, explaining that it is not under the English jurisdiction how French police authorities obtained evidence. In that sense, the court showed lack of sensibility and understanding of rules in other legal systems, and also breached the reliability principle ${ }^{43}$. Furthermore, even though evidence which was obtained under the foreign law, but in compliance with domestic principle, could not be accepted. Scottish court in the case of HM Advocate v. McKay ruled that sometimes irregularities can be excused and evidence admitted ${ }^{44}$. Again, legal predictability is lacking.

Above all, the request model has been shown to be very slow. Procedure under the request model is too complicated and is not suited for modern condition police cooperation. Proposal was given under the European Evidence Warrant, ${ }^{45}$ which is based on the mutual recognition of evidence. Article 4 regulates that EEW will be used for evidence which is already in the possession of the issuing state and which is not on the list, ${ }^{46}$ for the other evidence "old" request model will be applied. Although EEW has not entered into force yet, it is obvious that some changes are necessary.

Moreover, constant extension of the police powers has been proven with the availability mode, which has been established in Prum Treaty by several states. This model has been successful in transposing some provisions from the treaty

4242 Andre Klip, European criminal law, 2009: $1^{\text {st }}$ edition, Antwerp-Oxford-Portland, page no 378, EComHR, 4 September 1991, Chinoy v. United Kingdom, 15199/89, unpublished.

${ }^{43}$ Ilias Bantekas and Susan Nash, "International Criminal Law", second edition, first published in Great Britain 2003, by Chavendish Publishing Limited, London, p. 246.

${ }^{44}$ Ibid. p. 247.

${ }^{45}$ European Evidence Warrant, OJ L 350, 30/12/2008, p 72.

${ }^{46}$ European Evidence Warrant, OJ L 350, 30/12/2008, p 72, article 4, has establish exhausting list when evidence cannot be used. 
into Decision 2008/615 on Stepping up Cross-border Cooperation. ${ }^{47}$ The principle of availability is explained: "This means that a law enforcement officer in one Member State of the Union who needs information in order to carry out his duties can obtain it from another Member State and that the law enforcement authorities in the Member State that hold this information will make it available for the declared purpose." ${ }^{\prime 4}$ The main idea is to present on line check in databases for comparison and automated transfer of DNA material, fingerprints, vehicle registration data and similar; information may be used for preventing terrorist offences, but also for immediate investigatory purpose. The advantage of this model is that system of cooperation can be more efficient. Request is not necessary and there is no need to wait for the reply. On the other hand, a lot of debates have taken place about protection of the accused rights, especially data protection and right to privacy. So far, agreements have been regulated so that information may be exchanged between member-states under certain conditions; however the "principle of availability", now gaining ground, assumes that entire data sets may be forwarded without restrictions and without approval of the court ${ }^{49}$. Information has to be submitted simply because it is available.

In order to make the system functional, Member States have to establish DNA data bases, but it has not been specified what kind of data would be included, from which people? Might some countries collect DNA data not only from people convicted of serious crimes, but also from people who are suspects? Can we say that this is legal? In my opinion, it is a violation of human rights, considering especially how much damage can arise from a situation where someone is wrongly suspected. People often remain stigmatized by the crimes that they may not have committed. On the other hand, one might question where the limits of this model are. As individuals cannot say no to send their data, and legal remedies are not provided, it is clear that their rights are infringed. ${ }^{50}$ Moreover, it is still not unequivocal whether this model will enable requesting state to gather data from other countries, which it is not allowed to gather under its national law. ${ }^{51}$ That would give the police authority to go beyond its national law and would

${ }^{47}$ Council decision 2008/615/JHA of 23 Jun 2008 on stepping up of cross-border cooperation, particularly in combating terrorism and cross-border crime, available at OJ L 210, 6/8/2008.

${ }^{48}$ Council decision 2008/615/JHA of 23 Jun 2008 on stepping up of cross-border cooperation, particularly in combating terrorism and cross-border crime, available at OJ L 210, 6/8/2008, (4), and also Andre Klip, European criminal law, 2009: $1^{\text {st }}$ edition, Antwerp-Oxford-Portland, page no 354 .

${ }^{49}$ Christine Wicht, More security at any price, The Stockholm Program of the European Union, 24/03/2010,first published in Blätter fur deutsche und international Politik 3/2010 available at http://www.eurozine.com/articles/2010-03-24-wicht-en.html

${ }^{50}$ Andre Klip, op.cit., p.354.

${ }^{51}$ Valsamis Mitsilegas, EU Criminal Law, 2009: $1^{\text {st }}$ edition, Hart Publishing Ltd, Oxford, p. 262. 
infringe legal certainty. The question is what will prevail, the security and privacy of the individuals or the interest of the states? It is easy to conclude that exchange of this information will help police officers, but the price may be too high. The easy flow of, for example, data on bank accounts seriously infringes people's privacy. A consequence of automated transfer of material is that there is no control of condition under which data is transferred. In that sense legality of the information exchanged is questionable.

Once again it has been shown that criminal law has become ambiguous. Progress has been made only on one side. General opinion of the lack of protection of defence rights is present among lawyers, academics and professors. An individual's rights are not only violated during the investigation, exchange of data, but also during the trial, which is consequence of different rules for obtaining evidence. As has already been shown EEW is not an adequate solution. New methods for gathering and admissibility of evidence have to be established. Evidence collected under the EU rules has to be admitted as relevant. There are two possibilities for achieving this. One is greater harmonization of laws in preinvestigation phrase. Legal predictability and equality will be best secured in that way, but this seems very hard to achieve. A second possibility is represented in EEW, and that is mutual recognition of evidence. This would mean that all evidence which is collected lawfully under the national law of one state must be admitted in the proceedings of the other state. The problem which has already been mentioned is that different rules for obtaining evidence ${ }^{52}$ will lead to unequal standard for national cases and non national cases. Considering the abovementioned, the best solution might be a compromise. Therefore, imposing certain minimum rules or standards that have to be achieved for recognition of evidence, seems to be the right solution.

On the other hand, by establishing an institution such as EURODEFENSOR, greater balance would be achieved between the prosecution and defence. This was proposed in Alternative Project of Penal European Prosecution and further elaborated in European Programme of Criminal Law and Procedure. It would be financed by the EU, be independent and consist of two separate departments. One is the Legal Protection Department, which would be responsible for protecting the accused at the early, necessarily domestic, stage of the investigation and the other is the Support Department which would establish contact with defence counsel, coordinate defence and make information and financial resources available. ${ }^{53}$

${ }^{52}$ In some countries, suspected has rights to access to defense Council in $24 \mathrm{~h}$, upon his arrest by police, but in some others there is no such obligatory. If person is arrested by police of second mentioned country, and interrogated under their rules, judge of first mentioned country has to accept such evidence.

${ }^{53}$ Professor Dr h.c.mult. Bernd Schünemann, EURODEFENSOR, op.cit. p.15. 


\section{CONCEPT OF MULTILATERAL CO-OPERATION WITHIN EU}

Multilateral co-operation is the most successful European integration in the area of crime investigation. This unique type of co-operation and enforcement "does not necessarily or exclusively serve the interest of a specific EU Member State". ${ }^{54}$ Its features are quite different in comparison to other kinds of cooperation within the EU, bilateral co-operation. As it has been presented in the first part of the paper, the bilateral co-operation between the law enforcement authorities is based on the need of one Member State, on the one hand, and the ability of another to assist it, on the other. However, the former state will maintain the control over the process. ${ }^{55}$

On the contrary, in multilateral co-operation we can distinguish various procedures which could be initiated in the different ways depending on the MS role. Moreover, we usually cannot even recognize in which country's favour multilateral cooperation is initiated. Even if we have a case where the existence of a crime is clear, multilateral co-operation would have an aim to clarify the roles of the individuals involved and decide in which MS the proceedings will take place. Nonetheless, these decisions will not be made by a single Member State, but by their representatives in the bodies of multilateral cooperation. Multilateral co-operation, as such, is formed on three levels ${ }^{56}$ :

1. Police level

2. Prosecutorial level

3. Level of judges and courts

In this paper the focus will be only on the police level and its foremost part, Intelligence centre for strategic analysis-EUROPOL.

\subsection{EUROPOL: Intelligence Centre for Strategic Analysis \\ 3.1.1. History of Europol}

"It is interesting to analyze the creation of Europol, having emerged as a new plant in the international law enforcement garden after a long and difficult germination period." 57

The creation of Europol was characterized by constant battle between two approaches. The former one was centralizing approach regarding Europol as a

${ }_{55}^{54}$ Andre Klip, op.cit, p.383.

${ }^{55}$ Ibid.

${ }^{56}$ Ibid. p. 384.

${ }^{57}$ Treaty enforcement and international cooperation in criminal matters: with special reference to the Chemical Weapons Convention, Rodrigo Yepes-Enriquez, Lisa Woollomes Tabassi, Organisation for the Prohibition of Chemical Weapons, Cambridge University Press, 2002, page 285 . 
central, Union police force overseeing national police forces. The letter approach was more "intergovernmental" where the role of Europol was intended to be solely to enhance cooperation and coordination between police forces. The first aspect was strongly put forward in ' 80 s and ' 90 s with an idea of creating the "European FBI". However, the unsolved questions such as how many and what kind of powers should be given to Europol encountered strong resistance from a number of MS. The idea of European FBI remained far-fetched. Finally, a compromise was found. The basis for the Europol establishment was set for the first time in the Treaty on European Union in 1992. In 1994 Europol started only limited operations in the sphere of drug-related crimes as Europol Drugs Unit. The Europol Convention was signed a short time later, and came into force in 1998 followed by further Protocols. These legal acts have gradually widened the competences of the Europol. In 2002, the mandate of Europol was extended to deal with all serious forms of international crime listed in the Annex to the Europol Convention, which included terrorism and currency counterfeiting, racism and xenophobia, racketing and extortion...This process gathered momentum and culminated when Europol gained the most significant competencies on $6^{\text {th }}$ of April 2009. As of this date Europol became an EU body, as it was adopted in the Decision ${ }^{58}$ by the Council of the EU, Justice and Home Affairs, in Luxembourg. This Decision abounded with some fundamental differences:

- "Communitarisation" of Europol and move away from the "intergovernmental" concept

- Europol acquired a stronger mandate and new capabilities to fight international serious crime and terrorism and became able to assist investigations against serious crimes (for example: serious killer who was convicted of crimes in two or more MS)-not necessarily "organized crime"

- Europol has become a formal EU agency

- As a body of EU it will get its finances from the budget of the EU

- The opportunity to cooperate with third partners-Europol will be able to widen its sources of information because it can receive information from private parties

- Since legal instrument which regulates the work of Europol is no longer the Convention but the Decision, national parliaments have weaker control.

The Lisbon Treaty has increased responsibility of Europol, in order to establish more effective internal security within the EU. In that sense, the Director of Europol says: "This is a time of great opportunity for Europol and police cooperation in the EU. We will use this period of reform to our mandate and

58 COUNCIL DECISION of 6 April 2009 establishing the European Police Office (Europol) (2009/371/JHA), Official Journal of the European Union L 121/37, 15.5.2009. 
capabilities, and the opportunities afforded by the Lisbon Treaty, to establish Europol as the criminal information hub and principal operational support centre in the EU. Working in support of our Member States we are determined to play a major role in making Europe safer." ${ }^{159}$ It is important to acknowledge that even though Europol has wider competences after these changes, it still cannot be regarded as a federal police since there is no possibility to "carry out any operational activity in the territories of the MS since it does not enjoy autonomous law enforcement powers." 60

Since this brief analysis has shown in which direction the development of Europol is going, in the context of the defence rights, one crucial question remains: Are these increased competences in compliance with the available defence protection? Is there a good balance between security of the EU citizens, on the one hand, and restriction imposed on rights of the individual person, on the other?

This raises some concerns relating to Europol which will be presented after each analysis of the relevant issues explaining the work of Europol.

\subsubsection{Objective and tasks}

The Europol Decision (article 3$)^{61}$ stipulates that Europol shall strengthen cooperation between Member States in preventing and fighting organized crime, terrorism and other forms of serious crime when they affect two or more Member States. These objectives are to be achieved by fulfilling the tasks outlined in article 5 of the Decision. Europol has to facilitate the exchange of information between MS and also collect, store, process, and analyze the relevant information. It has an obligation to inform national authorities of any information concerning them and help the national investigation teams by forwarding the information. Europol may even ask MS to initiate, conduct or coordinate the investigation and to suggest the setting up of joint investigation teams. As been already acknowledged, Europol does not have executive powers, but, in some sense, it can be seen as partially operational already. "It also has powers to participate in joint investigation teams, something that in practice means that Europol officer may operate in the territory of a MS. In this context, the line between assisting and operating may be rather blurred."

$59 \mathrm{http} / /$ www.europol.europa.eu/index.asp?page=news\&news=pr100105.htm, visited on $24^{\text {th }}$ of April, 2010.

${ }^{60}$ Maria Fletcher and Robin Loof with Bill Gilmore, EU Criminal Law and Justice, 2008: first edition, Edward Elgar Publishing Limited.

${ }^{61}$ COUNCIL DECISION of 6 April 2009 establishing the European Police Office (Europol) (2009/371/JHA), Official Journal of the European Union L 121/37, 15.5.2009. 


\subsubsection{Mandate}

The Europol's mandate has been expanded to include serious international crime in a broad sense, even in the stages where there is merely reasonable ground to believe. According to article 4 of the Council Decision its competences include crimes which have to meet a number of conditions:

1. Organized crime, terrorism and other forms of international crime listed in the Annex to the Decision

2. Involved in two or more Member States

3. The crime requires a common approach

4. Scale, significance and consequences of the offences.

"Europol is entitled to deal with 32 crimes which are subject to "fasttracking" under the European arrest warrant and shall become more "operational" by being part of joint investigation teams. Thus, the mandate of Europol is no longer restricted to organized crime. ${ }^{.62}$ Moreover, Europol has a right to support a MS in organizing an international event with a public order policy impact.

In other words, Europol does not deal with minor crimes but with serious, transnational, organized crimes with European dimension. Competences of Europol go even further than that, considering the article 4(3) of the Decision. Those are related to criminal offences committed to procure the means of perpetrating acts in respect of which Europol is competent, in order to facilitate or carry out acts in respect of which Europol is competent or to ensure the impunity of act. Some of the crimes which are under Europol competences are defined in certain international or European legal instruments, since there are references to those instruments in the Annex to the Europol Decision. According to some authors, this is a safe mechanism since the Europol does not work on the same legal background as on the national level of Member States. ${ }^{63}$ However, in the opinion of the writers of this text, a person could notice that the respect for the principle of legality, nullum crimen sine lege, nulla poena sine lege, could be ostensible here. It could be seen that the list of other forms of serious crimes which Europol is competent to deal with, consists of solely listed names of crimes. As it has been mentioned above, some of them refer to the international conventions (for example, Council of Europe Convention on Laundering, Search, Seizure and Confiscation of the Proceeds from Crime, signed in Strasbourg on 8 November 1990). However, there are also crimes without definition, which means that police investigation (where the bulk of the evidences could be collected) based on the multilateral cooperation would be performed without knowing actual elements of the

${ }^{62}$ Elspeth Guild, Florian Geyer, Security versus justice: police and judicial cooperation in the European Union, 2008: $1^{\text {st }}$ edition, Ashgate Publishing, Ltd, p. 26.

${ }^{63}$ Andre Klip, op. cit., p. 390. 
crime. Some authors agree with this statement: "Although the Europol Convention defined the crimes which Europol was initially competent to deal with, none of the crimes over which Europol has subsequently gained competence has been defined." ${ }^{\prime 4}$ The solution in Annex is given in this way: "The forms of crime referred to in Article 4 and in this Annex shall be assessed by the competent authorities of the Member States in accordance with the law of the Member States to which they belong. ${ }^{65}$ Principle of legality is weakened since we do not have incrimination on the European level. Even in the cases where some description is given it is still vague and broad. However, this has not yet proved to be a significant problem since Europol only assists national investigations. In that sense, if Europol continues to develop in the same direction and acquires law enforcement powers in the future, this issue could cause more problems. Some authors suggest that if Europol gains law enforcement powers and becomes close to the concept of federal police, EU would need its own Criminal Code. In any case, it would be better to have a clear picture of where the limits of Europol competences are. Otherwise the legal protection of individuals seems to be weak.

\subsubsection{Relations between Europol and Member States}

In order to achieve efficiency, every MS has to establish a national unit, the only liaison body between Europol and the national authorities. According to Article 8, these national units are to be responsible for carrying out the tasks of Europol. There can be no direct contact between MS competent authorities and Europol. It always has to go via the national units. "The national units and Europol are to supply each other mutually with information and respond to request." ${ }^{, 66}$ Each national unit sends at least one liaison officer to Europol seat in Hague, who will represent interests of his MS. Liaison officers will assist in the exchange of information between their national unit and Europol, and they must give advice with regard to the analysis exchanged. ${ }^{67}$

\subsubsection{Computerized system of collected information}

Europol has established a three part system of the collected information:

1. information system (the so-called Europol Information System)

2. analysis work files (AWFs)

${ }^{64}$ Steve Peers, Europol: The final step in creation of an "Investigative and Operational" European Police Force, 2007, Statewatch analysis.

${ }^{65}$ COUNCIL DECISION of 6 April 2009 establishing the European Police Office (Europol) (2009/371/JHA), Official Journal of the European Union L 121/37, 15.5.2009.

${ }_{67}^{66}$ Andre Klip, op.cit, p. 390.

${ }^{67}$ Ibid. p. 391. 
3. index system. ${ }^{68}$

A) The Information system is the section where the national units and the liaison officers can directly enter data and from which they can directly extract data. That means that not every police or other law enforcement authority of the MS has access to the information system. It contains information which is a direct input of the Europol national units and liaison officers, as well as data which Europol itself inserted directly. The full range of data is only accessible via the liaison officers. This information system is tightly controlled and closed, since consequences of easy excess to it could be very dangerous-for example, it could warn people involved in criminal activity or put undercover officers or potential witnesses at risk. In the article 12 we can find three types of persons whose data could be inputted:

1. Persons suspected of having committed or having taken part in a criminal offence within the competence of EUROPOL

2. Persons who have been convicted of such an offence

3. Persons regarding whom there is justified and reasonable concern to believe that they will commit a criminal offence within the competence of Europol.

However, all data must contain a reference which indicates whether the data were provided by a third party or are the result of the Europol's own analysis.

The problematic issue here concerns exchange of data on persons for whom there are grounds for presuming that they will commit criminal offence (article 12 (b)). It has been stated by some authors that this provision is particularly dangerous with respect to rights of individuals, especially because of the question of how law enforcement agencies will decide that this is the case and whether the information processed by Europol results from unregulated policing methods ${ }^{69}$. These questions remain unanswered. This expression is too vague and ill-defined.

B) The Analysis work files system has purpose to analyze data which exist in the information system as well as much wider information. It does not concern only person mentioned in article 12 but also persons who could be used as witnesses in future proceedings, persons for whom there is a reason to believe that they could be victims in the future, or any other person who could provide useful information for the offence. As far as liaison officers are concerned, their right to access the work files is based upon the "need to know"

${ }^{68}$ Article 10 of the COUNCIL DECISION of 6 April 2009 establishing the European Police Office (Europol) (2009/371/JHA), Official Journal of the European Union L 121/37, 15.5.2009.

${ }^{69}$ Valsamis Mitsilegas, EU Criminal Law, 2009: $1^{\text {st }}$ edition, Hart Publishing Ltd, Oxford, page 186 .

${ }^{69}$ Andre Klip, op.cit. p. 395. 
principle, which means that they have to give sufficient reasons for participating in the analysis.

C) Index to the Analysis work files system is created for the data stored in the analysis work files. These indexes have to be created in a way to be clear to a person using them, as to whether they contain relevant data. In other words, liaison officers should be able to decide whether the case affects their country from the index description.

It has been stipulated that Europol can use this data only for the performance of its tasks and for the crimes under the scope of its competence. These systems are tightly closed and "the principle of availability is definitely not applicable to the flow of information from Europol". ${ }^{70}$ Even though there is a limited access, some authors claim that the potentials of Europol are rather sparsely used, since in reality it does not have as much information as it is supposed to contain. One explanation is that law enforcement authorities are reluctant to give all the information to Europol since that could lead to the success of another foreign entity, after all the work that has been previously done by someone else. "There is a little of enthusiasm to supply the information which will lead to seizure, arrest and prosecution in another Member State, when most of investigating work has been done at home.," could be the fact that MS do not have enough confidence in Europol. Even outside the EU there have been statements which show distrust of Europol's information system. $^{72}$

This analysis of Europol information systems has been down with the aim of showing how deep they could go into the privacy of the individual and to show the lack of the means of protection and remedies which are offered to an individual.

\subsubsection{Judicial and Political Accountability}

One of the most controversial issues in the development of Europol is the matter of judicial control. There has been constant refusal by some Member States to accept ECJ involvement. However, the problem of preliminary ruling procedure dates back to when Europol Convention was in force. Since it is sub-

${ }^{70}$ Ibid. p. 392.

${ }^{71}$ Ibid. See also Maria Fletcher and Robin Loof with Bill Gilmore, EU Criminal Law and Justice, 2008: first edition, Edward Elgar Publishing Limited.

${ }^{71}$ COUNCIL DECISION of 6 April 2009 establishing the European Police Office (Europol).

${ }^{72}$ FBI has stated: "Uncertainty and even distrust concerning the information/law enforcement intelligence process applied by Europol among the law enforcement community in the US" found in "Europol-USA agreement: Was it really needed?" Statewatch News online, July 2001:http://www.statewatch.org/news/2006/jul/01 europol-usa.htm. 
stituted with the Europol Decision, it is logical to presume that ECJ will have competences to interpret it. The Preamble of the Decision says that "judicial control will be exercised in accordance with article 35 of the TEU." However, in some opinions it seems this reference will not introduce any major changes to the current status quo ${ }^{73}$, due to the possibility for the MS to opt out of the ECJ jurisdiction on preliminary ruling (for example: UK).

On the other hand, political control performed by national parliaments is weakened since Europol Decision is the Council decision. However, since Europol will be financed from the EU budget European Parliament will have more significant control over it.

Nonetheless, critical issue of ECJ having no competences to protect the rights of individuals has to be emphasized. Some kind of accountability is ensured through national legal systems since every state which is responsible for the erroneous data inputted in Europol data base is liable for damages. Some authors stress that even the protection by national courts is limited since they are subordinate to the Joint Supervisory Body, "to the inviolability of Europol archives as well as to the immunity of Europol's officers." ${ }^{74}$ However, the problem of the lack of protection on the EU level remains huge because "any individual who is affected by such a misuse cannot appeal to the ECJ due to the lack of legal competences." 75

The following issue is about Joining Supervisory Body, described in Article 33 of the Decision. There was controversy between some states during the negotiations with Germany favouring a judicial type and France insisting on a purely administrative type. Regardless of what model is used, forming a JSB as an independent body is a key to accountability. Even though article 33 prescribes that MS will appoint its representatives who will constitute this body, there have been suggestions that "the power to select the members of the JSB to the European Parliament would be a significant step towards ensuring democratic accountability for Europol." 76

It can be concluded that the powers of Europol continue to expand in response to cross-border crimes. However, that does not justify restrictions on the rights of individuals and lack of political and judicial accountability. Furthermore, greater transparency will be helpful since it would increase public knowledge of its operations and a greater willingness to accept the expansion of its

\footnotetext{
${ }^{73}$ Mitsilegas, EU Criminal Law, 2009: $1^{\text {st }}$ edition, Hart Publishing Ltd, Oxford, p. 184.

${ }^{74}$ Elspeth Guild, Florian Geyer, Security versus justice?: police and judicial cooperation in the European Union, 2008: $1^{\text {st }}$ edition, Ashgate Publishing, Ltd, p. 26.

${ }^{75}$ Ibid.

${ }^{76} \mathrm{http}$ ://www.justice.org.uk, Justice, UK's legal and human rights organization, visited on $24^{\text {th }}$ of April, 2010.
} 
powers. In any case, better organization of Europol will be able to resist the transnational crime exploitation.

\subsubsection{The future of Europol alongside the future of the rights of individuals}

Since European Decision and Lisbon Treaty have introduced a lot of changes concerning Europol, the question is: whether those changes imposed measures for sufficient protection of the rights of individual?

Almost all authors agree on the one thing-this widening of powers has not been accompanied with major amendments in privacy framework. "What new safeguards are proposed to ensure the accountability of these new 'operational and investigatory powers'? None. There is no reference to national parliaments, no enhancement of supervision by the European Parliament, and no strengthening of the data protection regime, apart from the creation of a Data Protection Officer within Europol." 77

Extending Europol's powers to collect, exchange and analyze a wide range of personal date, on the one hand, while not securing enough safeguards, on the other hand (which is what happened in the new Europol Decision) is not acceptable. " ${ }^{78}$ "The expansion of Europol's powers poses great challenges for the protection of human rights in the EU, in particular privacy. In the light of these challenges, the adequacy of the current legislative framework governing Europol in terms of privacy protection, judicial control, transparency and accountability remains questionable.“79

In our opinion, the best solution at present would be to use all the potential of Europol within existing legal framework instead of constant widening of its powers. On the other hand, the balance which has been disturbed has to be restored again, by introducing better protection of individual privacy and human rights.

\section{CONCLUSION}

It is important to note that procedural safeguards and defence rights do not start with the proceedings before the court, but have to be respected during the investigation, in the pre-trial period, as well. This fact must not be forgotten on the national level, as well as on the European level when Europol, joint investigation teams and other forms of cooperation are concerned.

${ }^{77}$ Steve Peers, Human Rights Centre, University of Essex, Europol: The final step in the creation of the "Investigative and Operational" European Police Force, Statewatch ISSN 1756$851 X$.

${ }^{78}$ Valsamis Mitsilegas, op.cit. p.186.

${ }^{79}$ Ibid. p.187. 
From the analysis above, it could be concluded that the defence rights have to be set in such a way that they offer efficient protection of the individual both, on the theoretical and empirical level. In our opinion, it seems that EU fails on both levels at the moment. In that sense, some changes have to be introduced in order to address this problem.

Choosing between different solutions given by various authors, creation of the institution, such as EURODEFENSOR, would be sufficient progress. "This model has the decisive advantage of matching an institutionally strengthened prosecution by an equally powerful institutionalized defence body." ${ }^{\prime 80}$ The way we see its possible function, it would be active in the cases of serious crimes with cross-border element. EURODEFENSOR would monitor and ensure the respect for the rights of the accused in cases where Eurojust is active and no defence council is involved yet.

Finally, the crucial point is to preserve the fundamental values which present the basis on which the Member States and the EU are settled. Fight against crime has to be taken seriously, but not at the expense of human rights, rule of law and democracy.

${ }^{80}$ Professor Dr.Dr.h.c.mult. Bernd Schunemann, EURODEFENSOR, op.cit. p.15. 
Тијана Жунић, адвокайски ириирравник у Новом Саду

Тијана Ђукић, адвокайски ирииравник у Новом Саду

\section{Права осумњиченог и полицијска сарадња у Европској Унији}

\section{Сажнейак}

Укидање граница у Европској Унији донело је многе бенефиције обичним европским грађанима омогућивши слободно кретање људи, робе, капитала и услуга. Са друге стране, такве промене погодовале су и разним криминалним и терористичким организацијама. У том смислу, борба против организованог криминала са националног нивоа морала је да пређе на виши ниво, билатералну и мултилатералну сарадњу држава чланица ЕУ. У покушајима да сузбију разгранати криминал државе чланице су уводиле различите мере у оквиру своје новооформљене сарадње, нарочито у сфери преткривичног поступка и истраге. То је довело до проблема нарушеног баланса између заштите права осумњиченог лица, са једне стране и овлашћења органа унутрашњих послова, са друге. Поставља се питање да ли је Европска Унија заборавила на темеље Европске цивилизације, људска права и слободе, дубоко задирући у приватност и право на одбрану осумњиченог. Одговарајући на исто аутори овог рада су представили развој и јачање полицијских овлашћења на три нивоа, а у контексту права појединца. Први део рада односи се на анализу овог проблема на националном нивоу појединих држава чланица. Други део објашњава билатералну кооперацију држава чланица, док се трећи део фокусира на најважнији вид мултилатералне сарадње, Еуропол и његове недостатке.

Кључне речи: Европско кривично право, права осумњиченог лица, билатерална сарадња, ЕВРОПОЛ. 